\title{
The determinants of Șukūk issuance in GCC countries
}

\author{
Imene Guermazi
}

Imam Muhammad ibn Saud Islamic University, Riyadh, Saudi Arabia

\begin{abstract}
Purpose - This paper focuses on Șuk̄ k issuance determinants in Gulf Cooperation Council (GCC) countries. Given the dual characteristic of debt and equity of $S u k \bar{u} k$ as well as their unique benefits of social responsibility, the author questions whether the theories of capital structure, the trade-off and the pecking order are able to well explain the Sukūk issuance.

Design/methodology/approach - First, the author verifies these theories using capital structure determinants and regresses the $S u k \bar{u} k$ change on these determinants. Second, the author tests the trade-off theory with the target debt model and third, verifies the pecking order theory using the fund flow deficit model. Findings - The empirical results show that capital structure determinants fail to explain both theories. The author confirms that the Sukūk change is significatively linked to the deviation from a Suku $k$ target. So, issuing firms balance the marginal costs of $S u k \bar{u} k$ and their benefits of religiosity and social responsibility toward a target debt. The author finds no evidence of the pecking order theory.

Research limitations/implications - This study contributes to corporate finance theory and corporate social responsibility. It verifies if capital structure theories proved in conventional financing can well explain Islamic bonds issuance given their social responsibility benefits.

Practical implications - Managers and investors would pay attention to the social factors explaining $S u k \bar{u} k$ issuance in their finance and investment decisions. They would be enhanced to use this financing tool knowing its social unique benefits. This also should encourage governments to enhance this socially responsible financing. Rating agencies would be motivated to evaluate $S u k \bar{u} k$ and firms would improve the quality and relevance of disclosure to get the best rating.

Social implications - The author highlights the social factors explaining $S u k \bar{u} k$ issuance and enhances corporate social responsibility (CSR).

Originality/value - The author extends the few literature testing capital structure theories for Islamic bonds and highlights the specific social responsible features of Sukuk that would bridge their issuance to capital structure theories. So the author enhances the concept of Islamic CSR. Tying capital structure theories to CSR would also help developing Islamic finance theory as a unique social responsible framework.
\end{abstract}

Keywords Social responsibility, Pecking order theory, Șukuk issuance, Trade off theory

Paper type Research paper

\section{Introduction}

Financing decision involves decision on the composition between debt and equity and the decision on type of financial securities to be issued. Many studies on corporate finance have dealt with debt-equity choice and associated shareholders' wealth effect. Researchers have focused on the determinants of bond issuance. They have proved theories of capital structure, mainly the pecking order theory and the trade-off theory. The trade-off theory predicts that there is an optimal debt ratio maximizing the value of a firm. This optimal leverage is determined by a trade-off between the marginal costs and benefits. In contrast, the pecking order theory suggests instead a pecking order of financing choice generated by the problem of information asymmetry (Myers and Majluf, 1984; Rajan and Zingales, 1995;

\section{JEL Classification — G110, G120, G320. KAUJIE Classification - K16, I73, L4}

(C) Imene Guermazi. Published in Islamic Economic Studies. Published by Emerald Publishing Limited. This article is published under the Creative Commons Attribution (CC BY 4.0) license. Anyone may reproduce, distribute, translate and create derivative works of this article (for both commercial and non-commercial purposes), subject to full attribution to the original publication and authors. The full terms of this license may be seen at http://creativecommons.org/licences/by/4.0/legalcode

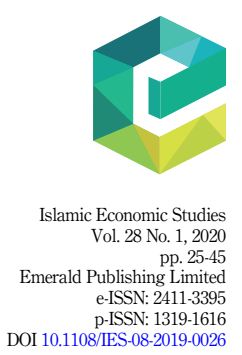

Received 27 August 2019 Revised 17 November 2019 Accepted 21 June 2020

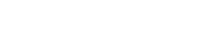


IES

28,1

Al-Sakran, 2001; Kayo and Kimura, 2011; Psillaki and Daskalakis, 2009; Vasiliou et al., 2009; Shyam-Sunder and Myers, 1999; Frank and Goyal, 2003).

There is a scarcity of empirical research dealing with the choice involving another debt type security, i.e. the sukukk. Compared to conventional bonds that promise to pay interest, which is prohibited in Sharı'ah, sukuk $k$ allow ownership in the underlying economic assets and pay either profit or rent of those assets. Thus, sukuk have unique benefits of religiosity and making socially responsible finance embedded in them. Besides, the profit-sharing principle implies that sukuk represent fractional ownership in an underlying asset or project. Sukuk holders receive part of the profit proportional to their fractional ownership, which confers them the dual status of lenders and investors. So, sukuk have the hybrid nature of debt and equity. Given these features of religiosity, embedded Islamic corporate social responsibility (CSR) and the hybrid nature of debt and equity, we question if capital structure theories can well explain șukuk issuance.

Researchers have regressed șukuk amount on capital structure determinants to examine if $s u k \bar{u} k$ issuance is explained by these theories. Nagano (2016) finds no evidence of pecking order theory but does not confirm the trade-off theory. Other authors find some evidence of trade-off theory (Shahida and Saharah, 2013; Hanifa et al., 2014; Mohamed et al., 2015). However, Azmat et al. (2014) find no evidence of debt ratio target in Malaysian șukukk. Very few studies have tested if the theories of capital structure explain șukuk issuance in GCC countries. Using capital structure determinants, Grassa and Miniaoui (2018) find mixed results supporting both the trade-off and the pecking order theories.

Existence of only few studies focusing on $s u k \bar{u} k$, with little evidence of capital structure theories, make it difficult to stipulate that sukuk issuance can be well explained by either trade-off or pecking order theories. In this paper, we contribute to fill this gap by testing these theories in GCC countries using not only capital structure determinants but also the debt target model and the fund flow deficit model.

We address the research question of whether capital structure theories can explain șukuk issuance in GCC countries. We use the accounting data of GCC șukuk issuing firms for the period 2005-2016. Our results show that capital structure determinants fail to confirm either the trade-off theory or the pecking order theory. Indeed, the amount of șukuk depends significantly and negatively on profitability and significantly and positively on earning volatility which is contrary to the trade-off theory. Thus the trade-off theory is rejected. Besides, the pecking order theory is not confirmed since it also predicts a negative sign of the coefficient of earning volatility. However, the trade-off theory is proved using the target level debt model. In fact, we find that the suku $k$ change is significantly linked to the deviation from a șukuk target. So, șukūk issuance aligns toward an optimal leverage. This target is determined by a trade-off between the marginal costs and social responsibility benefits of the $s u k \bar{u} k$, which confirms the trade-off theory. We also perform the fund deficit flow model to test the pecking order model. But the results reject the pecking order theory.

This study contributes to corporate finance theory and CSR. It checks if the capital structure theories proved in conventional finance can as well explain Islamic bonds issuance given their social responsibility benefits. It would help defining the social factors that encourage Sukukk issuance. This would reasonably lead to Islamic finance and Islamic CSR development.

The remainder of this paper is organized as follows: the first section deals with the conceptual approach and literature review. The second section presents the methodology. Section three presents the sample study, while section four reports the descriptive statistics. Section five is about results and section six is about discussion.

\section{Conceptual approach and literature review}

This paper verifies if capital structure theories are able to explain $s u k \bar{u} k$ issuance. We present the theoretical and empirical literature on capital structure theories and șukuk. 


\subsection{Capital structure theories}

Many corporate finance studies have pointed out that trade-off theory and pecking order theory are major determinants of conventional bond issuance. The trade-off theory has contradicted the theorem of Modigliani and Miller (1958) that postulated no leverage impact on firm's value. On the contrary, the trade-off theory predicts that there is an optimal debt to equity ratio maximizing the value of a firm. This optimal leverage is determined by a trade-off between the marginal costs and benefits (Kraus and Litzenberger, 1973; Myers, 2001; Van Binsbergen et al., 2011). In contrast, the pecking order theory does not predict a target debt ratio. It suggests instead a pecking order of financing choice generated by the problem of information asymmetry. The information asymmetry concerns the bigger knowledge of shareholders/managers about the value of the firm assets and future growth prospect. To overcome this problem, shareholders/managers prefer internal financing to external financing. Besides, in case of external financing, they opt for debt prior to equity to reduce information cost (Myers and Majluf, 1984; Rajan and Zingales, 1995; Al-Sakran, 2001; Kayo and Kimura, 2011; Psillaki and Daskalakis, 2009; Vasiliou et al., 2009).

A first part of these researches in this field has tested these theories using determinants related to capital structure, which are mainly profitability, growth opportunities tangibility, non-debt tax shields, volatility and size. Another part assumes that firms target a particular leverage induced by a trade-off between the securities costs and benefits. A third part uses the funds flow deficit model to assume that in case of deficits, the firm will only issue or retire equity as a last resort. The major part of these researches deals with conventional bonds, while very few authors focus on Islamic bonds.

\subsection{Researches using capital structure determinants}

Authors in this field have observed the relation between debt and capital structure determinants relating to profitability, growth opportunities, tangibility, non-debt tax shields, volatility and size.

2.2.1 Profitability. Concerning profitability, the trade-off model argues that profitable firms are less likely to be subject to bankruptcy risk because of their increased ability to meet debt repayment obligations. Thus, they will demand more debt to maximize their tax shield at more attractive costs of debt. The pecking order theory predicts the opposite sign suggesting that high profitable firms will be able to generate more funds through retained earnings and then have less leverage. Compared with debt and equity, retained earnings have no adverse selection problem, and hence, they are the cheapest source of finance (Myers and Majluf, 1984; Rajan and Zingales, 1995; Al-Sakran, 2001; Kayo and Kimura, 2011; Psillaki and Daskalakis, 2009; Vasiliou et al., 2009).

2.2.2 Asset tangibility. The trade-off theory predicts that the risk of lending to firms with more tangible assets is expected to be low, given the higher liquidation value of these assets in the event of financial distress or bankruptcy. Therefore, a firm with a higher percentage of fixed assets is expected to borrow more as compared relatively to firms with smaller fixed asset. Thus, we expect a positive relationship between tangibility of assets and debt (Harris and Raviv, 1991; Rajan and Zingales, 1995; Hovakimian and Li, 2011). In contrast, the pecking order theory predicts that firms with few tangible assets are more sensitive to informational asymmetries. Thus, these firms will issue debt rather than equity when they need external financing, which leads to negative relation between asset tangibility and debt (Titman and Wessels, 1988).

2.2.3 Firm size. Under a trade-off framework, larger firms have higher debt capacity and can borrow at more favorable risk-adjusted interest rates than smaller firms. Also, they are more diversified and less susceptible to bankruptcy (Titman and Wessels, 1988). Therefore, we expect a positive relationship between size and debt (Harris and Raviv, 1991;

Sukūk issuance determinants in GCC countries 
IES

28,1

Rajan and Zingales, 1995; Shyam-Sunder and Myers, 1999). However, according to the pecking order theory, larger firms are more closely observed by the investment community and thus less subject to information asymmetry than small firms (Rajan and Zingales, 1995).Thus, they should be more capable of issuing equity, which is more sensitive to information asymmetry and have lower debt (Rajan and Zingales, 1995). We suggest a negative relation between firm size and leverage.

2.2.4 Growth opportunities. According to the trade-off theory, low-growth firms should use debt because it has a disciplinary role to alleviate the free cash flow problem (Jensen, 1986; Stulz, 1990). Hence, we expect a negative relationship between debt and growth opportunities. Pecking order theory predicts that growth opportunities should be financed with equity instead of debt. In order to mitigate moral hazard, a negative relationship is expected between debt and growth opportunities (Smith and Watts, 1992). However other authors claim that internal funds may be insufficient for highly growing firms, which will tend to issue debt, thus leading to a positive correlation between debt and growth opportunities (Myers, 1977; Titman and Wessels, 1988).

2.2.5 Non-debt tax shield. In the trade-off scheme, firms consider non-debt tax shields, such as depreciation and investment tax credit deductions, as a substitute for the tax shield and will have less incentive to increase leverage for tax considerations. So, non-debt tax shields and debt should have a negative relationship (Titman and Wessels, 1988; Fama and French, 2002; Flannery and Rangan, 2006). On the other hand, pecking order theory does not offer any judgments on the relationship between debt and non-debt tax shield.

2.2.6 Volatility. In the context of volatility, the trade-off theory assumes that firms with high earnings volatility try to accumulate cash during good years to avoid under-investment problems in the future (Myers, 1977). As DeAngelo and Masulis (1980) point out, an adverse selection problem is more severe to firms with highly volatile earnings. To avoid adverse selection problem, firms with financial surpluses should retire debt or invest in cash or marketable securities, to preserve their debt capacity for future financing needs or to avoid issuing equities at higher costs (Myers, 1984). Higher volatility of earnings increases the probability of financial risk and these firms will face the difficulties in debt financing. According to Jensen (1986), the pecking order theory also suggests the negative relationship between leverage and earnings volatility.

\subsection{Researches using target leverage model}

Authors of these papers assume that firms target a particular leverage. If the actual ratio differs from the target, the firm would adjust its debt or equity to achieve the target. Researchers in this field have regressed the long-term debts change scaled by the total asset on the deviation of the debt ratio from its target value (Bradley et al., 1984; Long and Malitz, 1985; Rajan and Zingales, 1995; Titman and Wessels, 1988; Taggart, 1977; Marsh, 1982; Auerbach and King, 1983; Jalilvand and Harris, 1984; Opler and Titman, 1994; Graham and Harvey, 2001; Marsh, 1982, Hovakimian et al., 2001; Ozkan, 2001; Fama and French, 2002; Flannery and Rangan, 2006; Lemmon et al., 2008; Huang and Ritter, 2009).

\subsection{Researches using fund flow deficit model}

Researchers in this field regress the firm's net debt issues on its net financing deficit. The financing deficit is defined using the cash flow identity, as the growth in assets less the growth in current liabilities (except the current portion of long-term debt) less the growths in retained earnings. According to this identity, this deficit must be filled by the net sale of new securities. Except for firms at or near their debt capacity, the pecking order predicts that the deficits will be filled entirely with new debt issues. Authors in this field find that the estimated coefficient on the deficit variable is close to one and interpret this result as evidence 
supporting the pecking order theory because a shortfall in funds is first met by debt (ShyamSunder and Myers, 1999; Frank and Goyal, 2003).

\subsection{Capital structure theories for Islamic bonds}

To state capital structure theories for $s u k \bar{u} k$, we begin by analyzing their specific features

2.5.1 Hybrid nature of sukuk. The word sukuk is the plural of Arabic word sakk which has the literal meaning of legal instrument/certificate, deed or cheque. The Accounting and Auditing Organization for Islamic Financial Institutions (AAOIFI, 2017) defines șukuk as follows: "Suku $k$ are certificates of equal value representing undivided shares in ownership of tangible assets, usufruct and services or (in the ownership of) the assets of particular projects or special investment activity." In other words, șukuk provide ownership of a part of the underlying asset to the holders. These certificates are rewarded with a pre-agreed profitsharing rate and thus avoiding any interest-based transaction.

So, sukūk combine characteristics of conventional bonds and stocks. Like bonds, they have a face value, a maturity date, a remuneration rate and provide a regular stream of cash flows to investors including capital refunding with a margin. However, unlike bonds, the return on the sukukk is generated from an underlying asset, not from the obligation to pay interest. Thus, they share some common features with capital-like instruments as they give the right of a stream of revenue from an investment project (Miller et al., 2007; Nathif and Thomas, 2004; Klein and Weil, 2016; Wilson, 2008). This hybrid nature is influenced by the

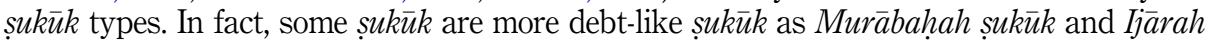

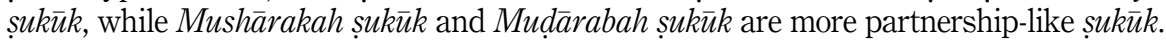

2.5.2 Benefits of sukūk: religiosity and corporate social responsibility. Șukūk are desirable by Sharíah-conscious investors and entrepreneurs for their religious content. Hence, $s u k \bar{u} k$ offer unique benefit of strong adherence to Islamic financial directives. Shafron (2019) and Paltrinieri et al. (2019) explain the effect of this religious benefit on the choice of sukukk investment using the theory of "investor tastes" of Fama and French (2007). According to this theory, "investor tastes" are persistent in nature and exist when certain investors "get direct utility from their holdings of some assets, above and beyond the utility from general consumption that the payoffs on the assets provide". Specifically, investors with a taste for Shariah-compliant investments achieve a higher utility from investing in Sharíah-compliant investments even with lower expected cash flows, than they would if they had instead held non-Shariah-compliant investments with higher expected cash flows. The investors' tastes of religiosity should encourage firms to meet these needs by issuing sukuk $k$. Moreover, the Islamic entrepreneurs may themselves have a taste for Shariah-compliant financing and thus a higher utility from issuing sukuk, than they would if they issue instead non-Sharíahcompliant securities. So, religiosity influences the behavior of stock market investors and issuers. These unique benefits should encourage firms to choose to issue sukūk.

Besides, sukuk presents another unique benefit of Islamic CSR. CSR is the recognition on the part of management of an obligation to the society it serves not only for maximum economic performance but for humane and constructive social policies as well (Heald, 1957). The most notable theory inherent to this concept is Freeman's (1984) stakeholder theory. This theory assumes that sharing values with stakeholders is necessarily and explicitly a part of doing business (Freeman, Wicks and Parmar, 2004). Islamic finance implements a variation of the conventional CSR, the Islamic CSR. Indeed, it is based on the ethical principles embodied in the Sharíah (Islamic legal and ethical system), where its underlying objective are generally aimed at realizing overall human wellbeing and social justice (Ullah and Jamali, 2010). One of the most important ethical principles is the ban of interest. Thus, investors of șukuk are paid dividends on the outcome of profit-sharing agreements between issuers and investors instead of fixed interest installment payments as in normal bonds (Siddiqi, 1987). Therefore, șukuk
Sukūk issuance determinants in GCC countries

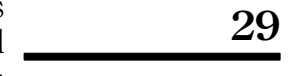


IES

28,1

integrate social concerns building justice between the money holder and the entrepreneur. On the one hand, the suku $k$ holder is not unfairly assured of a positive return without doing any work or sharing in the risk, while the entrepreneur, in spite of his management and hard work, will bear all the risk to provide guaranteed return to the capital provider. On the other hand, Islamic finance presents schemes of risk management and insurance of șkuk respectively by special purpose vehicle (SPV) and Takaful. The SPV maintains the underlying asset to ensure the returns stream while Takaful alleviates the risk of asset loss. So, Islamic bonds further social benefits beyond financial interest with requests for collective welfare.

Empirically, authors focusing on ethical activities prove the beneficial effect of social responsibility on the raise of the corporate value through an increase in additional equity investment from the external investors. They find significant relation between CSR indicators and measures of financial performance such us ROA, ROE, market-to-book ratio, Tobin's $q$ and cost of equity (Jensen et al., 2002; Heinkel et al., 2001; Graff Zivin and Small, 2005; El Ghoul et al., 2011; Lee and Faff, 2009; Eccles et al., 2013; Dixon-Fowler et al., 2013; Marti et al., 2013; Hu, 2019). Other authors deal with the unique benefits of religiosity and Islamic CSR. Shafron (2019) shows that investors with Islamic beliefs tend to invest more in $s u k \bar{u} k$ than they would without such beliefs. Specifically in Ramadan, Klein et al. (2017) and Bialkowski et al. (2012) assert that religiosity can influence the investor behavior and find that investors react more positively to the $s u k \bar{u} k$ issuance than conventional bonds. Similarly, some authors suggest positive market reaction to șkūk issuance (Nagano, 2010; Mohamed et al., 2017). Although other authors find evidence of negative market reaction to șukūk issuance (Ahmed et al., 2018; Ameer and Othman, 2010; Modirzadehbami and Mansourfar, 2011; Godlewski et al., 2013; Hasib et al., 2017). Mohamed et al. (2017) relate these latter findings to the longer time taken by investors to absorb the information from the sukuk announcement. Indeed, they prove a significantly positive reaction 30 days after the announcement of șukuk issuance.

2.5.3 Capital structure determinants of suku $\bar{k}$. The hybrid nature of șk $\bar{u} k$ and their unique benefits of Islamic CSR and religiosity address the issue of whether capital structure theories can explain suku $k$ issuance. Some authors argue that the profit-sharing type of this financing tool depends on greater internal information of the issuers when investors would like to receive maximum dividends. Therefore, the information cost of $s u k \bar{u} k$ issuance is predicted to be between normal debt finance and equity issuance. Thus, the choice of $s u k \bar{u} k$ is accordingly subordinated to normal debt finance but prior to equity issuance according to pecking order theory (Nagano, 2010; Nagano, 2016; Azmat et al., 2014). However, other authors reject the pecking order theory and claim that firms choose to issue suku $k$ independently of the internal funding and the information cost. So, according to the trade-off theory, the firm opts for a target ratio of sukuk to assets to maximize its value. This optimal leverage is determined by a trade-off between the marginal costs and benefits of the șukuk (Shahida and Saharah, 2013; Mohamed et al., 2015). As șukuk benefits are inherent to religiosity and social responsibility, the trade-off prediction supposes that issuing firms balance the costs and the benefits of religiosity and social responsibility benefits of sukukss.

\subsection{Researches dealing with determinants of Islamic bonds issuance}

Very few studies focus on the determinants of $s u k \bar{u} k$ issuance. Islamic corporate finance research has investigated whether capital structure theories explain șukuk issuance. Some authors have performed logit and probit models to analyze the determinants of șukuk and conventional bonds issuance. They have tested if these determinants relate to pecking order, trade-off or timing theory. One of these researchers, Nagano (2010) finds evidence that Malaysian firms choose to issue șukuk prior to bank borrowing and other external 
financing tools. He shows that șukuk issuance does not relate to the issuer's internal funds or to the information cost, but that Islamic bank borrowing always does. The author explains the results by the fact that firms issue șukuk to obtain other benefits no matter how large the information cost is. He shows that firms obtain an increase in the corporate value by issuing sukuk $k$, which must be due to its ethical benefits. He concludes that suku $k$ issuance is preferentially chosen as a funding scheme because it brings unique financial and ethical benefits.

Nagano (2016) did not find any evidence of the pecking order theory in a comparative study concerning Malaysia, Saudi Arabia and the United Arab Emirates. His findings show that the possible determinants of șukuk are firm size and past șukuk issuance. The insignificant relationship with other variables also indicates that șukuk is considered to be chosen prior to the normal bond issuance regardless of the availability of firms' internal funds. In another study concerning Malaysia and Indonesia, Nagano (2017) proves that the pecking order theory explains suku $k$ issuance decision in case of large funding demand. Indeed, he finds that, under high information asymmetry, a firm with a high stock price and a large demanding fund prefers sukūk issuance to conventional debt. Focusing on specific șukūk type, Azmat et al. (2014) performed probit model on utility function to test Malaysian issuers' choice of Islamic bonds. They show that Islamic joint venture bonds do not align with debt-equity target, while secured against real estate these sukūk do not always represent ownership of the underlying asset. Shahida and Saharah (2013) use OLS, fixed effect and random effect models to prove that suku $k$ issuance depends on firm size, past șukuk issuance experiences and finally the government tax incentive. These findings are consistent with trade-off theory; however, leverage and profitability remain insignificant for suku $k$ issuance decisions.

Hanifa et al. (2014) perform the partial adjustment model to find the firm specific determinants of target debt ratio. Using șukuk and conventional bond issuance dataset for the period 2000 to 2012, the results of the dynamic panel data estimators provide strong support for trade-off theory. However, when the authors took consideration of bond and suku $k$ types, they show, on the one hand, that partnership-based șukuk and convertible bonds follow pecking order theory. On the other hand, straight bonds and exchange-based șukuk align toward a target debt.

In GCC countries, Grassa and Miniaoui (2018) use capital structure determinants and find mixed results. Aligning with the pecking order theory's predictions, they document a positive relation between growth opportunity and $s u k \bar{u} k$ issuance and a negative correlation between size and șukuk issuance. However, concerning asset tangibility, their results support the positive sign of the trade-off theory.

These studies provide little evidence that capital structure theory can explain șukukk issuance.

\section{Methodology}

In this paper, we test first the trade-off theory and the pecking order theory using capital structure determinants. Second, we apply the target debt model to verify the trade-off theory. Third, we use the fund flow deficit model to test the pecking order theory. In the current section, we present the methods of each model. To deal with the problems of heteroscedasticity and serial correlation in the residuals, we use techniques of panel estimation: fixed effects model and random effects model. We also use the instrumental variable technique to resolve the problem of lagged independent variable

\subsection{The capital structure model}

This model aims to verify if $s u k \bar{u} k$ issuance is explained either by trade-off theory or by pecking order theory using capital structure determinants. We will examine if șuku $k$ amount 
IES

28,1

32

is influenced by determinants of capital structure, which are profitability, growth opportunities, tangibility, non-debt tax shields, volatility and size.

3.1.1 Hypotheses. Some authors argue that the profit-sharing type of șukuk depends on internal information of the issuers when investors would like to receive maximum dividends. However, the information cost of $s u k \bar{u} k$ issuance is predicted to be inferior to equity issuance. Thus, the choice of sukuk is prior to equity issuance according to pecking order theory. However, according to trade-off theory, the firm opts for a target ratio of $s u k \bar{u} k$ to assets to maximize its value. This optimal leverage is set by a trade-off between the marginal costs and benefits of the sukuk (Nagano, 2010; Nagano, 2016; Shahida and Saharah, 2013; Azmat et al., 2013).

The trade-off theory anticipates a positive relation between leverage and the capital determinants tangibility, size and profitability and a negative relation with growth opportunities, non-debt tax shields and volatility. However, the pecking order theory predicts that leverage depends positively on growth opportunities and negatively on profitability, tangibility, size and volatility.

Hence, we posit the following hypotheses:

H1. According to the trade-off theory, sukūk issuance is positively influenced by tangibility, profitability and size and negatively related to growth opportunities, non-debt tax shields and volatility.

H2. According to the pecking order theory, sukūk issuance is positively influenced by growth opportunities and negatively related to size, profitability, tangibility and volatility.

3.1.2 Econometric models. To test Hypothesis 1, we regress șukuk on these lagged determinants using the following model

$$
\begin{aligned}
\Delta s \operatorname{uk} \bar{u} \mathrm{k} / \text { assets }_{i t}= & a+b_{1} \text { Profitability }_{i t-1}+b_{2} \text { Tangility }_{i t-1}+b_{3} \text { nondebt tax shields }_{i t-1} \\
& +b_{4} \text { Volatility }_{i t-1}+b_{5} \text { Size }_{i t}+b_{6} \text { Growrh }_{i t}+\varepsilon_{i t}
\end{aligned}
$$

To test Hypothesis 2, we regress șukuk on these lagged determinants using the following model

$$
\begin{aligned}
\Delta s \operatorname{suk} \bar{u} \mathrm{k}_{i t} \text { assets }_{i t}= & a+b_{1} \text { Profitability }_{i t-1}+b_{2} \text { Tangility }_{i t-1}+b_{3} \text { Volatilit }_{i t-1}+b_{4} \text { Size }_{i t} \\
& +b_{5} \text { Growth }_{i t}+\varepsilon_{i t}
\end{aligned}
$$

3.1.3 Variable measures. In the two econometric models, the dependent variable is sukuk, while the independent variables are capital structure determinants, notably profitability, growth opportunities, tangibility, non-debt tax shields, volatility and size.

(1) Sukūk

Sukuk is measured by the ratio of the amount of șukuk divided by total assets

(2) Profitability

This variable is measured by the ratio of earnings before interest and taxes to the total assets (Following Titman and Wessels, 1988; Rajan and Zingales, 1995).

(3) Growth opportunities

Following Rajan and Zingles (1995) and Bevan and Danbolt (2002, 2004), we use the ratio of market-to-book value as a proxy for growth opportunities. 
(4) Tangibility

We adopt the ratio of fixed assets to the total assets in line with Rajan and Zingales (1995) and Bevan and Danbolt (2004).

(5) Size

As well as Titman and Wessels (1988) and Rajan and Zingales (1995), we employ the natural logarithm of total assets as proxy for the size of the firms.

(6) Non-debt tax shields

We calculate it by the ratio of annual depreciation to total assets as done in prior researches (Titman and Wessels, 1988; Ozkan, 2001).

(7) Earning volatility

Following Titman and Wessels (1988), we use the standard deviation of return on assets as measure of volatility of earnings, where the return on assets for each year is measured by the ratio of earnings before interest and taxes to the total assets.

\subsection{The debt target model}

The debt target model aims to verify if $s u k \bar{u} k$ issuance is explained by the trade-off theory using the target debt prediction.

3.2.1 Hypothesis. The trade-off theory indicates that a firm aims to achieve an optimal capital structure of debt and equity that is determined by the trade-off between marginal costs and benefits. We suppose that the marginal social responsibility benefits of suku $k$ issuances also impact a firm's capital structure. So, according to the trade-off theory, the firm opts for a target ratio of sukuk to assets to maximize its value. This optimal leverage is generated by a trade-off between the marginal costs and benefits of the suku $k$. The prediction of this model assumes that firms target a particular leverage. If the actual ratio differs from the target, the firm would adjust its șukuk to achieve the target. We will examine if the șukuk change is linked to the deviation from a șukuk target.

Thus, we propose the subsequent hypothesis:

H3. According to the trade-off theory, sukük change is significantly linked to the deviation from a șukuk target.

3.2.2 Econometric model. Hypothesis 3 will be verified using the partial adjustment model of debt (Gaud et al., 2005; Drobetz and Wanzenried, 2006; Flannery and Rangan, 2006). This model is specified as follows:

$$
\Delta \operatorname{Debt}_{i t}=a+\gamma\left(\text { Debt }_{i t}^{*}-\text { Debt }_{i t-1}\right)+\varepsilon_{i t}
$$

Where Debt $_{i t}^{*}$ : the target debt level for firm $i$ at time $t$.

We replace debt by Sukukk and set the following model

$$
\Delta S \operatorname{Su} \bar{u} k_{i t}=a+\gamma\left(S \operatorname{Suk} \bar{u} \mathrm{k}_{i t}^{*}-\operatorname{S} u k \bar{u} k_{i t-1}\right)+\varepsilon_{i t}
$$

Where $S u k \bar{u} k_{i t}^{*}$ : the target debt level for firm $i$ at time $t$.

$S u k \bar{u} k_{i t}^{*}=\beta X_{i t}+\varepsilon_{i}, X_{i t}$ : Vector of explanatory variables, identified by the capital structure theories. So, we use the same explanatory variables of the precedent models, profitability, growth opportunities, tangibility, non-debt tax shields, volatility and size.

This model measures the change in debt between two periods. The first term on the right side of the equation is the speed of adjustment, $\gamma$; the speed by which firms adjust toward their
Sukūk issuance determinants in GCC countries 
IES

28,1

target șukuk ratio from their șukuk ratio in the previous period. To deal with the endogeneity problem, we use as instrument the sector of activity.

3.2.3 Variable measurement. The dependent variable is change in șukuk, while the independent variable is the difference between target șukuk and șukuk .

(1) Change in șukūk

It is the difference of suku $\bar{k}$ in two successive periods. However, for many cases the amount of $s u k \bar{u} k$ of the year before issuance is zero. This would create problems in the measurement of this variable. Therefore, we scaled șuku $k$ by total assets.

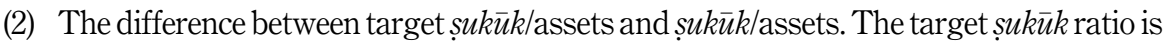
measured as:

$s u k \bar{u} k /$ Assets $^{*}=b X_{i t}$, where $X_{i t}$ is a vector of the capital structure determinants used.

\subsection{The fund flow deficit model}

This model tests the pecking order theory using the funds flow deficit model.

3.3.1 Hypothesis. This model predicts that the firm will only issue or retire equity as a last resort. It fills its deficit by using only debt. Therefore, the coefficient of the regression of debt change on funds flow deficit would be close to one (Shyam-Sunder and Myers, 1999; Frank and Goyal, 2003). We predict that this model can be applied for șukukk. As șukūk have hybrid nature of debt and equity, they can be appropriated to fill firms deficit, thus letting equity issuing as a last resort. We set the Hypothesis 4.

H4. The coefficient of the regression of debt change on funds flow deficit is close to one 3.3.2 Econometric model. We test Hypothesis 4 using the following model:

$$
\Delta S u k \bar{u} k_{i t}=\alpha+\beta \text { po } \mathrm{DEF}_{i t}+\varepsilon_{i t}
$$

Where DEF is the funds flow deficit

3.3.3 Variables measurement. The independent variable is the sukuk change, while the dependent variable is the funds flow deficit.

(1) Change in șukūk

This variable should be calculated as the variation of the amount of $s u k \bar{u} k$ scaled by total of assets.

(2) The funds flow deficit DEF

The funds flow deficit DEF which is measured as follows:

$$
\mathrm{DEF}_{t}=\mathrm{DIV}_{t}+X_{t}+\Delta W_{t}+D_{i t}+R_{t}-C_{t}
$$

Where, $\mathrm{DIV}_{t}$ : dividend payments; $X_{t}$ : capital expenditures; $\Delta W_{t}$. net increase in working capital; $R_{t}$ : current portion of long-term debt at start of period; $C_{t}$ : operating cash flows, after interest and taxes. $\mathrm{D}_{i t}$ : is the amount of debt issued or retired.

\subsection{Statistical tools}

We use techniques of panel estimation: fixed effects model and random effects model to deal with the problems of endogeneity of lagged dependent variable, heteroscedasticity and serial correlation in the residuals. The random effects model can be viewed as a regression model with a random constant term. This model assumes independence between the error term and the explanatory variables. However, the fixed effect model is a regression model with a fixed 
constant term. This model assumes correlation between the error term and the explanatory variables and uses deviations from individual averages to eliminate persistent differences between firms. The Hausman test allows us to choose the appropriate model for the sample. For each regression we perform the two methods. Then, we perform the Hausman test to choose the appropriate model for the sample. We also use the Wooldridge autocorrelation to verify if there is a need for autoregressive panels. To deal with the endogeneity problem, we use the instrumental variable technique. We perform these estimations using STATA tool.
Sukūk issuance determinants in GCC countries

\section{Sample and data}

The sample of the study includes sukvek issuing firms of GCC countries with available requested data. Thus, the retained countries are KSA, UAE, Oman and Qatar. Three firms were excluded for non-available data. We observe 19 issuing firms from 2004 to 2016. These firms are included only at the year of issuance, so we obtain an unbalanced sample of 36 observations. As demonstrated by Arellano (2003), the results provided by unbalanced panels are as reliable as those based on balanced panels. Furthermore, we believe the sample size is suitable according to Austin and Steyerberg (2015) who proved that the number of subjects per variable required in linear regression analyses for adequate estimation of regression coefficients, standard errors and confidence intervals is only two. So, the minimum required sample size in our case would be 12 . Moreover, we reviewed all studies dealing with minimum sample size for panel data using fixed effects and random effects models. There are no studies determining the minimum individual-level sample size. However, researches examining the group-level sample size show that predictors at either level are unbiased with 30 clusters and remain unbiased with as few as 15 clusters (Baldwin, S.A and Fellingham, 2013; Bell et al., 2014; Maas, C and Hox, 2004, 2005). By analogy, as we have 19 firms, we believe our results are unbiased. As we include $84 \%$ of the firms of the population of issuing firms, then our sample is representative.

We collect data from DATASTREAM.

Table 1 presents the list of the issuing firms and the types of $s u k \bar{u} k$, when available.

\section{Descriptive statistics}

We compute in Table 2 the descriptive statistics of the three models of study: the capital structure determinants, the target level and the fund flow financing.

Concerning the capital structure model, we remark that the standard deviation of the part of $s u k \bar{u} k$ in assets, the economic profitability, the ratio of depreciation to assets and the return to equity are inferior to 0.1 . This indicates that issuing amount, profitability, nondebt tax shields and earning volatility are relatively heterogeneous among the sample. However, the standard deviation of (ln assets) and the market-to-book ratio are superior to 1. Indeed, the market-to-book ratio varies from 0.230 to 15.730 and (ln assets) varies from 8.020 to 19.577. This indicates that the firms of the sample have different size and growth opportunities.

Regarding the target leverage model, Table 2 shows that change in șukuk varies from 0.327 to 0.327 , with an average of 0.057 and a standard deviation of 0.090 . This indicates that the sign of this variable is not the same for all the firms, but it doesn't have a big variation. Concerning the difference between $s u k \bar{u} k$ and the target $s u k \bar{u} k$, it varies from 0.856 to 2.349 , with an average of 1.868 and a standard deviation of 0.789 . This indicates that this change has the same sign in the sample and it has a big variation.

The descriptive statistics of the dependent and independent variables of the fund flow deficit model show that $s u k \bar{u} k$ varies from 0 to 0.327 , with an average of 0.058 and a standard deviation of 0.071 . This indicates that $s u k \bar{u} k$ does not have a big variation in the sample. 


\begin{tabular}{|c|c|c|}
\hline Firms & Issuance date & Type \\
\hline \multicolumn{3}{|l|}{ KSA } \\
\hline SABIC & $\begin{array}{l}9 \text { July } 2006 \\
22 \text { July } 2007 \\
26 \text { May } 2008\end{array}$ & NA \\
\hline Dar Al Arkan & $\begin{array}{l}28 \text { May } 2014 \\
24 \text { May }+25 \text { Nov } 2013 \\
18 \text { Feb } 2010 \\
\text { April } 2009 \\
\text { March } 2007\end{array}$ & Wakālah \\
\hline Saudi International Petrochemical Company & 06 Jul 2011 & Muḍārabah \\
\hline Saudi Electricity Company & $\begin{array}{l}\text { 01 Apr } 2014 \\
\text { 08 Apr + 4 Aug } 2013 \\
\text { 04 Apr + 26 Jun } 2012 \\
\text { 10 May 2010 } \\
\text { 06 Jul 2009 } \\
\text { 01 Jul } 2007\end{array}$ & Ijārah \\
\hline National Petrochemical Company (Petrochem) & 01 Jun 2014 & Murābahah \\
\hline Fawaz Abdulaziz Alhokair Company & 26 May 2014 & \\
\hline Advanced Petrochemical Company & 18 Nov 2014 & \\
\hline Najran Cement Company & 14 Jun 2015 & \\
\hline National Shipping Company of Saudi Arabia (Bahri) & 30 Jul 2015 & Murābahah \\
\hline \multirow[t]{2}{*}{ Almarai } & 17 Sep 2015 & NA \\
\hline & $\begin{array}{l}30 \text { Sep } 2013 \\
07 \text { Mars } 2012\end{array}$ & \\
\hline \multicolumn{3}{|l|}{$U A E$} \\
\hline Aldar Properties & 03 Dec 2013 & Ijārah \\
\hline Damac & 22 Sep 2015 & Ijārah \\
\hline DP World & 29 May 2016 & Hybrid \\
\hline \multirow[t]{4}{*}{ Emaar } & 15 Sep 2016 & Murābahah \\
\hline & 18 Jun 2014 & \\
\hline & 18 Jul 2012 & \\
\hline & 03 Aug 2011 & \\
\hline Drake and Scull International & 12 Nov 2014 & Murābahah \\
\hline \multirow[t]{2}{*}{ Majid Al Futtaim } & 03 Nov 2015 & Wakālah \\
\hline & 08 Feb 2012 & \\
\hline \multicolumn{3}{|l|}{ Qatar } \\
\hline Ezdan Holding & 18 May 2016 & Wakālah \\
\hline Ooredoo QSC & 12 Mar 2013 & Murābahah \\
\hline \multicolumn{3}{|l|}{ Oman } \\
\hline Omantel & 03 Feb 2016 & Wakālah \\
\hline
\end{tabular}

Concerning the fund flow deficit, it varies from -0.408 to 75,661 , with an average of 12,809 and a standard deviation of 0.789 . This indicates that this variable does not have the same sign in the sample and it has a big variation, which would have an important effect on the sign of its coefficient.

\section{Estimation results}

We present first the estimation results relative to capital structure determinants model. Then we report the results of the target leverage model and finally we show the results of the fund flow deficit model. 


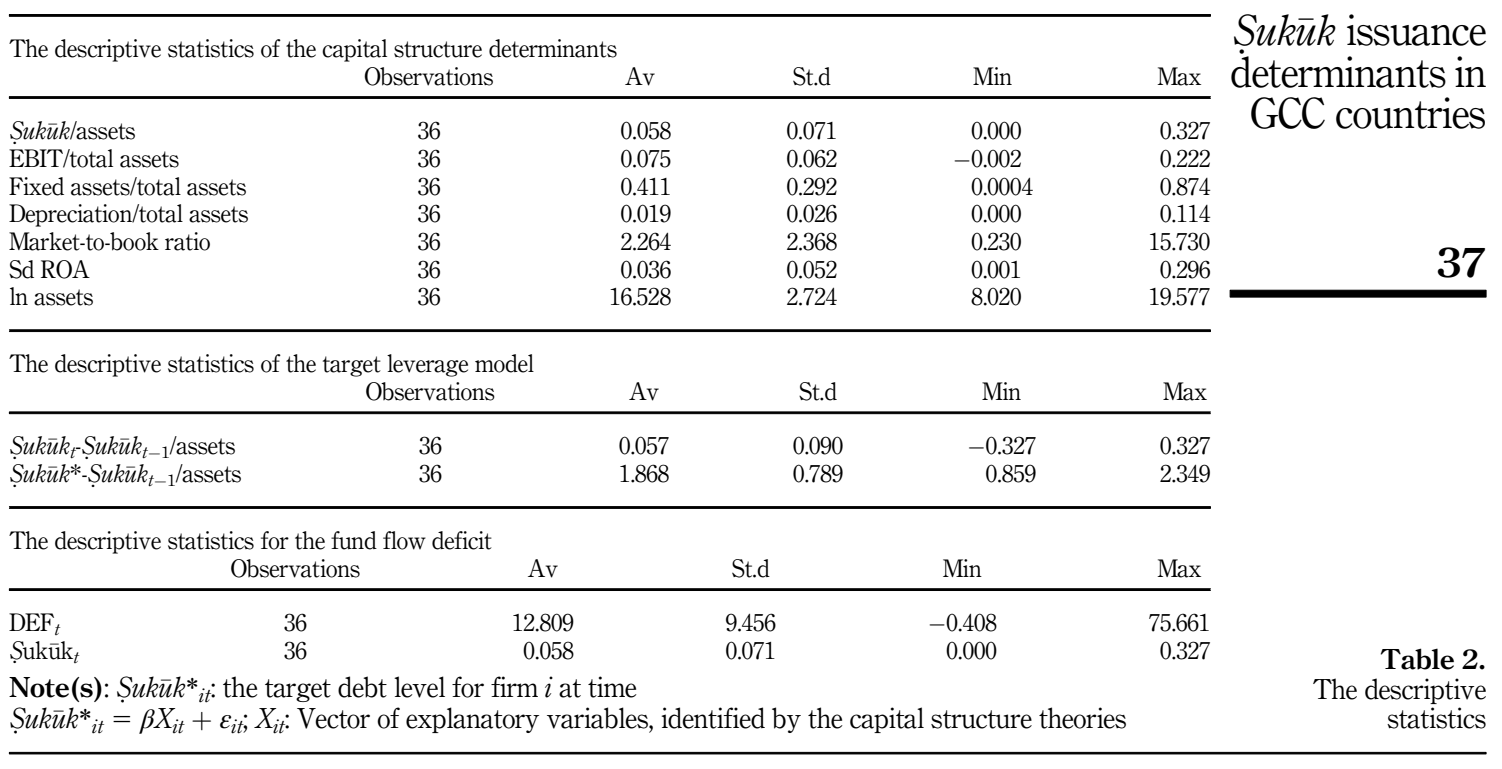

\subsection{Results of capital structure determinants}

Table 3 verifies if $s u k \bar{u} k$ issuance is explained by capital structure determinants. Specification 1 presents the results relative to the trade-off theory while specification 2 reports the results relative to the pecking order theory.

The results of specification 1 show that Wooldridge autocorrelation test rejects serial collinearity, so there is no need to perform autoregressive panel. Besides, the Hausman test recommends using fixed effect models. Two variables are significant to the $5 \%$ level;

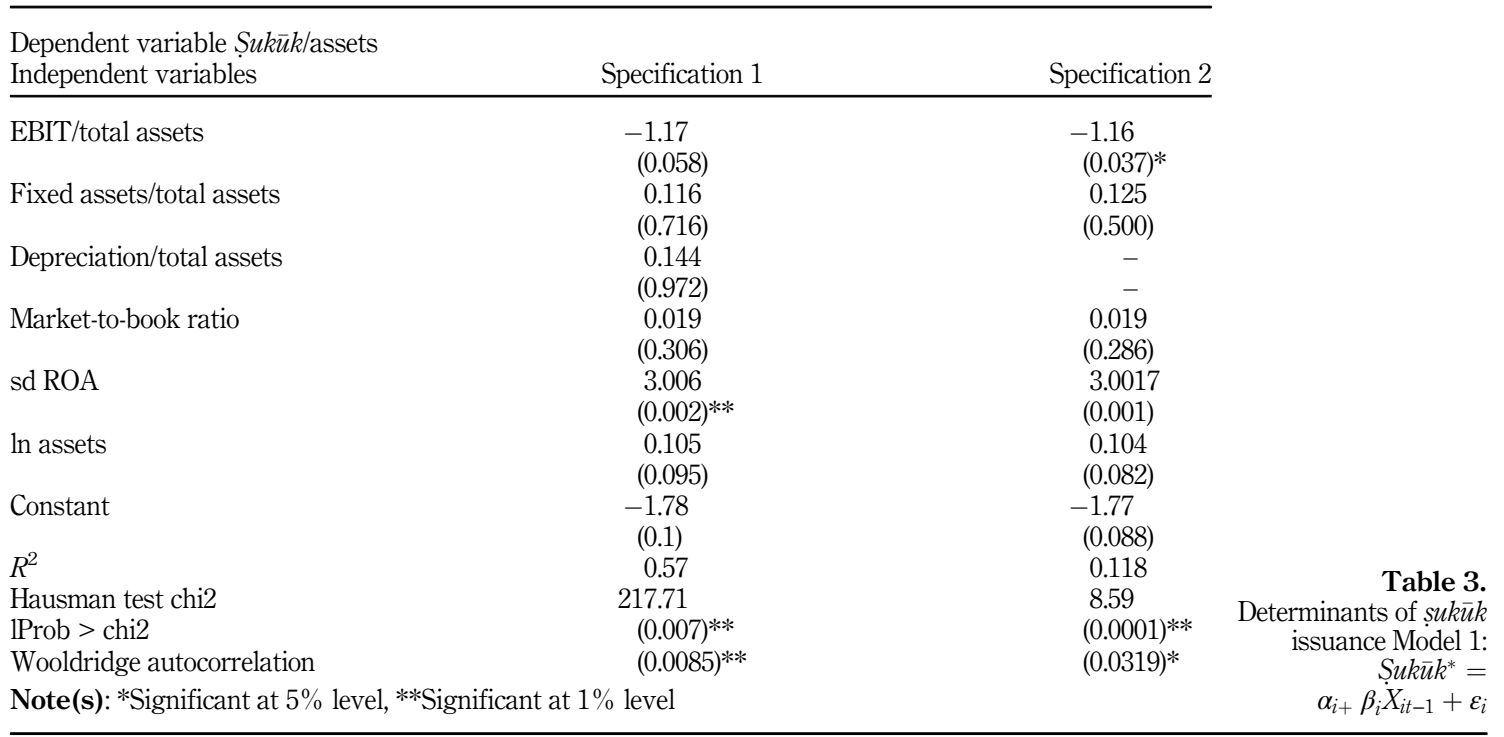


IES

28,1

\section{8}

profitability measured by the ratio (EBIT/assets), earnings volatility proxied by earnings standard deviation and size measured by (ln assets). However, the signs of these variables do not confirm the trade-off theory. In fact, the sign of profitability is negative, which is contrary to the trade-off theory. Besides, the sign of volatility is positive, which is contrary to the predicted sign. Hypothesis 1 is rejected, sukuk issuance is not positively influenced by tangibility, profitability and size and negatively related to growth opportunities, non-debt tax shields and volatility.

Specification 2 shows the results concerning the capital structure determinants of the pecking order theory. Wooldridge autocorrelation test rejects serial collinearity, so there is no need to perform autoregressive panel. Besides, the Hausman test recommends using fixed effect models. The same variables of specification 2 are significant to the $5 \%$; profitability measured by the ratio (EBIT/assets) and earnings volatility proxied by earnings standard deviation and size measured by (ln assets). Also, the signs of these variables do not all confirm the pecking order theory. In fact, the sign of profitability is negative, which is confirming to the pecking order theory. Nevertheless, the signs of volatility is positive, which is contrary to the predicted sign. Hypothesis 2 is rejected, and $s u k \bar{u} k$ issuance is not positively influenced by growth opportunities and negatively related to size, tangibility and volatility.

\subsection{The results of the leverage target model}

We present the results in Table 4. Wooldridge autocorrelation test rejects serial collinearity, so there is no need to perform autoregressive panel. Besides, the Hausman test is significant, thus recommending fixed effect model. The variable $\left(S \mathrm{uk} \bar{u}{ }_{*}{ }_{i t}-S \mathrm{uku} \mathrm{k}_{i t-1}\right)$ is significant to the $1 \%$ level. Hypothesis 3 is confirmed, suku $k$ change is significantly linked to the deviation from a șukuk target. So, the amount of șukuk converges to a target level following a trade-off between marginal costs and benefits of $s u k \bar{u} k$. Therefore, we find evidence of trade-off theory.

\subsection{The results of the funds flow deficit model}

These results are reported in Table 5

We notice in Table 5 that the Hausman test is not significant, which recommends random effect model. Wooldridge autocorrelation test rejects serial collinearity, so there is no need to perform autoregressive panel. The coefficient of the variable (funds flow deficit) is positive but not close to one. It is also not significant. Hypothesis 4 is rejected, the coefficient of the regression of debt change on funds flow deficit is not close to one. So, funds deficit is not filled by using only debt. Thus, the pecking order theory is rejected.

\begin{tabular}{|c|c|}
\hline $\begin{array}{l}\text { Dependent variable } \\
\text { Independent variables }\end{array}$ & $\Delta S \operatorname{suk} \bar{u} k_{i t}$ \\
\hline$S u k \bar{u} k_{i t}^{*}-S \operatorname{u} u \bar{u} k_{i t-1}$ & $\begin{array}{l}0.062 \\
(0.000)^{* *}\end{array}$ \\
\hline Constant & $\begin{array}{l}-0.33 \\
(0.000)\end{array}$ \\
\hline$R^{2}$ & 0.6831 \\
\hline Hausman test chi2 & 20.37 \\
\hline Prob > chi2 & 0.000 \\
\hline $\begin{array}{l}\text { Wooldridge autocorrelation } \\
\text { Instrumented } S u k \bar{u} k_{.}^{*}-S u k \bar{u} k_{i t-}\end{array}$ & $(0.00)^{* *}$ \\
\hline $\begin{array}{l}\text { Instruments } \\
\text { It }\end{array}$ & activity \\
\hline Note(s): *Significant at $5 \%$ level, **Significant at $1 \%$ level & \\
\hline
\end{tabular}

Table 4.

Target debt prediction Model 2: $\Delta S \operatorname{s} u \bar{u} k_{i t}=$ $a_{i}+\gamma\left(S ⿱ S u k \bar{u} k_{i t}^{*}-S \operatorname{uk} u\right.$ $\left.k_{i t-1}\right)+\varepsilon_{i t}$
Note(s): *Significant at $5 \%$ level, **Significant at $1 \%$ level 


\section{Robustness check}

We check the robustness of our results in many ways. First, we use techniques of panel estimation: fixed effects model and random effects model to deal with the problems of endogeneity of lagged dependent variable, heteroscedasticity and serial correlation in the residuals. For each regression we perform the two methods. Then, we perform the Hausman test to choose the appropriate model for the sample. We also use the Wooldridge autocorrelation to verify if there is a need for autoregressive panels.

Second, we test capital structure theories using three models to corroborate our findings. The model of capital structure determinants tests if sukuk change depends on capital structure determinants. The debt target model verifies if the firm targets a ratio of sukuk to assets determined by a trade-off between the marginal costs and benefits of the sukuk. The fund flow deficit model predicts that the firm will fill its deficit by using only debt only letting issuing equity as a last resort. We deal with the endogeneity problem using the instrumental variable technique. The capital structure model fails to prove either the trade-off theory or the pecking order theory. The debt target model proves the trade-off theory, while the funds flows deficit model rejects the pecking order theory. Thus, our findings are robust.

However, we do not use alternative measures of the significant independent variables. Indeed, the variables measures are chosen according to the review of previous researches, which used specific measures.

\section{Discussion of results}

We test if capital structure theories can explain sukūk issuance using three models; the capital structure determinants model, the debt target model and the fund flows deficit model. The model of capital structure determinants fails to confirm either trade-off theory or pecking order theory. We find that some of the coefficients of the variables measuring these determinants present signs conform to the predicted signs while other coefficient have signs contrary to the predicted signs. These mixed results are in line with those of Grassa and Miniaoui (2018). In fact, the authors document a positive relation between growth opportunity and șukuk issuance and a negative correlation between size and $s u k \bar{u} k$ issuance, which confirm the pecking order theory's predictions. However, they report a positive sign of asset tangibility, which verify the trade-off theory while leverage and profitability remain insignificant for suku $k$ issuance decisions. Our results conform also those of Nagano (2010) and Nagano (2016) that sukuk issuance is not related to the issuer's internal funds or the information cost and that size is a possible determinant of $s u k \bar{u} k$. Though, our findings differ from the one of Nagano (2016) that, under high information asymmetry, a firm with a high stock price and a large demanding fund prefers $s u k \bar{u} k$ issuance to equity, thus proving the pecking order theory. Our findings are also different from those of Shahida and Saharah (2013) that sukuk issuance depends on firm size.

\begin{tabular}{|c|c|c|}
\hline $\begin{array}{l}\text { Dependent variable } \\
\text { Independent variables }\end{array}$ & Șukūk $\mathrm{k}_{i t}$ & \\
\hline $\mathrm{DEF}_{i t}$ & $\begin{array}{c}0.003 \\
(0.248)\end{array}$ & \\
\hline Constant & $\begin{array}{l}1.89 \\
(0.006) * *\end{array}$ & Table 5 \\
\hline $\begin{array}{l}\text { R2 } \\
\text { Hausman test chi2 } \\
\text { Prob }>\text { chi } 2\end{array}$ & & $\begin{array}{r}\text { Table } \mathbf{b} \\
\text { Fund flow deficit model } \\
\text { Model 3: } S u k \bar{u} k_{i t}= \\
a_{i}+\gamma \mathrm{DEF}_{i t}\end{array}$ \\
\hline $\begin{array}{l}\text { Note(s): *Significant at } 5 \% \text { level, **Significant at } 1 \% \text { level } \\
\left.\operatorname{DEF}_{i t} \text { (Funds flow deficit }\right)_{i t}\end{array}$ & & $\begin{array}{r}\text { (Funds flow deficit })_{i t}+ \\
\varepsilon_{i}\end{array}$ \\
\hline
\end{tabular}

Sukūk issuance determinants in GCC countries 
IES

28,1

But unlike them, we do not prove that șukuk issuance depends on past șukuk issuance experiences and the government tax incentive.

To deal with our mixed results, we perform the leverage target model and then the fund flow deficit model. The results of the target sukuk model show that the amount of sukuk converges to a target level confirming the trade-off theory. This evidence implies that suk $\bar{u} k$ is a desirable financing tool and the firm aims to have a mixed financial structure of equity and $s u k \bar{u} k$. We explain this attraction by the unique benefits of $s u k \bar{u} k$. In fact, the hybrid nature of $s u k \bar{u} k$ and its interest-free scheme of outcomes made them an Islamic CSR way to rise funds. This suggestion aligns the findings of authors focusing on ethical activities, which have proven that social responsible activities not only improve the consumer's credibility, but also increase corporate value through an increase in additional equity investment from the external investors (Jensen et al., 2002; Heinkel et al., 2001 and Graff Zivin and Small, 2005; El Ghoul et al., 2011; Lee and Faff, 2009; Eccles et al., 2013; Dixon-Fowler et al., 2013; Marti et al., 2013; Hu, 2019). Nagano (2010) and Mohamed et al. (2017) have also suggested that sukuk brings unique benefits by increasing issuer's stock returns.

However, the results of the fund flows deficit model reject that funds deficit is filled by using only debt. So, pecking order theory is rejected. These findings are contrary to those of Shyam-Sunder and Myers (1999) and Frank and Goyal (2003) that fund deficit is filled by the net sale of new conventional debt securities.

As our results confirm the trade-off theory and reject the pecking order theory, we assume that firms do not choose to issue suku $k$ because of asymmetric information or its cost, but for their social unique benefits that other external financing don't afford.

\section{Conclusion}

In this paper, we verify if $s u k \bar{u} k$ issuance is explained by theories of capital structure. We extend the literature testing these theories for Islamic bonds. Previous research failed to find evidence of any capital structure theory outlining șukuk $k$ issuance in GCC countries. Our study further tests these theories and adds theoretical and empirical contributions. Theoretically, we highlight the specific features of sukuk that would bridge their issuance to capital structure theories. Sukuk are couched in the ethical principles embodied in the Sharíah (Islamic legal and ethical system). The underlying objectives of Sharíah are generally aimed at realizing overall human wellbeing and social justice. Indeed, suk $\bar{u} k$ conform to the principle of no interest and risk sharing. This principle promotes social justice between șukuk holders and issuing firms. Indeed, investors are not allowed to realize financial gains without being exposed to the risk of potential loss. So, in case of profits, they are paid dividends on the outcome of profit-sharing agreements. Therefore, Islamic bonds (sukukk) have hybrid nature between debt and equity. Besides, they offer unique benefits of religiosity and socially responsible financing. This hybrid nature as well as the social and religious benefits are the specific features linking suku $k$ issuance to capital structure theories.

Methodologically, this study adds empirical evidence by using three models, in contrast to previous studies dealing with only one model. Using the model of capital structure determinants, our results show that șukuk issuance is negatively and significantly linked to profitability. This sign confirms the pecking order theory. Nevertheless, $s u k \bar{u} k$ issuance is positively and significantly linked to earnings volatility, which is contrary to both trade-off theory and pecking order theory. Thus, the model of capital structure determinants does not permit to confirm or reject capital theories. So, we used the debt target model to test the tradeoff theory and the fund flow deficit model to test the pecking order theory. Our results show that șuku $k$ converge to a target level determined by a trade-off between the cost and the social responsibility benefits of $s u k \bar{u} k$. These findings are consistent with the trade-off theory. In addition, the test of the fund flow deficit shows that funds deficit is not filled by using only 
debt, thus rejecting the pecking order theory. Overall, we find evidence of the trade-off theory. We suggest that firms aim to have a target level of sukuk in their financial structure due to their unique benefits of religiosity and Islamic CSR.

Our findings present a number of implications for theory and practice. From the theoretical side, this paper contributes to the corporate finance theory and CSR. It highlights the important contribution of corporate Islamic finance to the development of CSR. Indeed, Islamic finance is embedded in ethical and social principles. One important principle is the ban on interest in financing and its replacement by profit-and-loss-sharing. The adoption of this principle in $s u k \bar{u} k$ induces unique social benefits with claims of social justice between $s u k \bar{u} k$ holders and issuing firms. These unique benefits, that other financing schemes do not give, link capital structure theories to CSR. Our research enhances the concept of Islamic CSR. Tying the capital structure theories to CSR would also help developing Islamic finance theory as a unique socially responsible framework. The socially responsible aspect is obvious as the unfair features such as the interest and risk bearing are replaced by the ethical principles of no interest and risk sharing. Therefore, the core of Islamic finance theory is to tailor conventional finance to socially responsible aims.

The main practical implications relate to the actors intervening in the financing process. One important outcome is to encourage managers and investors to further contribute to promote this Islamic financing tool for its unique social and Shariahcompliance benefits. Our results would encourage governments to enhance firms to adopt this socially responsible financing. Moreover, it would motivate them to issue sovereign $s u k \bar{u} k$, which constitutes a pricing benchmark and an anchor security for portfolio management and secondary trading. Furthermore, rating agencies would be motivated to evaluate $s u k \bar{u} k$ and ascertain the quality of issuance and subsequently attract more investors. To get the best rating, firms would improve the quality of disclosure and the relevance of their accounting information. This would reasonably lead to socially responsible financing development.

\section{References}

Accounting and Auditing Organization for Islamic Financial Institutions (AAOIFI) (2017), Shan' $a h$ Standards, 2017, Dar AlMaiman for publishing and distributing, Manama.

Ahmed, H., Hassan, M.K. and Rayfield, B. (2018), "When and why firms issue șukūk?”, Managerial Finance, Vol. 44 No. 6, pp. 774-786.

Al-Sakran, S.A. (2001), "Leverage determinants in the absence of corporate tax system: the case of non-financial publicly traded corporations in Saudi Arabia", Managerial Finance, Vol. 27, pp. 58-86.

Ameer, R. and Othman, R. (2010), "Stock market reaction to bonds issuance: evidence from Malaysian banking sector", International Research Journal of Finance and Economics, Vol. 45, pp. 161-169.

Arellano, M. (2013), Panel Data Econometrics (Advanced Texts in Econometrics), Manuel Arellano, Oxford University Press, Oxford University, London.

Auerbach, A.J. and King, M.A. (1983), "Taxation, portfolio choice, and debt-equity ratios: a general equilibrium model”, Quarterly Journal of Economics, Vol. 98, pp. 587-610.

Austin, P. and Steyerberg, E.W. (2015), "The number of subjects per variable required in linear regression analyses", Journal of Clinical Epidemiology, Vol. 68 No. 6, pp. 627-636.

Azmat, S., Skully, M. and Brown, K. (2013), "The shariah compliance challenge in islamic bond markets", Pacific-Basin Finance Journal, Vol. 28, pp. 47-57.

Azmat, S., Skully, M. and Brown, K. (2014), "Issuer s choice of islamic bond type", Pacific-Basin Finance Journal, Vol. 28, pp. 122-135.
Sukūk issuance determinants in GCC countries 
IES

28,1

Baldwin, S.A. and Fellingham, G.W. (2013), "Bayesian methods for the analysis of small sample multilevel data with a complex variance structure", Psychological Methods, Vol. 18, pp. 151-164.

Bell, B.A., Morgan, G.B., Schoeneberger, J.A., Kromrey, J.D. and Ferron, J.M. (2014), "How low can you go? An investigation of the influence of sample size and model complexity on point and interval estimates in two-level linear models", Methodology: European Journal of Research Methods for the Behavioral and Social Sciences, Vol. 10, pp. 1-11.

Bevan, A. and Danbolt, J. (2002), "Capital structure and its determinants in the UK - a decompositional analysis", Applied Financial Economic, Vol. 12 No. 3, pp. 159-170.

Bevan, A.A. and Danbolt, J. (2004) "Testing for inconsistencies in the estimation of UK capital structure determinants", Applied Financial Economics, Vol. 14, pp. 55-66.

Bialkowski, A., Etebarib, A. and Wisniewskic, T.P. (2012), "Fast profits: investor sentiment and stock returns during Ramadan”, Journal of Banking and Finance, Vol. 36 No. 3, pp. 835-845.

Bradley, M., Jarrel, G.A. and Kim, I.H. (1984), "On the existence of an optimal capital structure: theory and evidence", The Journal of Finance, Vol. 39 No. 3, pp. 857-878.

DeAngelo, H. and Masulis, R. (1980), "Optimal capital structure under corporate and personal taxation”, Journal of Financial Economics, Vol. 8, pp. 3-29.

Dixon-Fowler, H.R., Slater, D.J., Johnson, J.L., Ellstrand, A.E. and Romi, A.M. (2013), "Beyond does it pay to be green? A meta-analysis of moderators of the CEP-CFP relationship", Journal of Business Ethics, Vol. 112 No. 2, pp. 353-366.

Drobetz, W. and Wanzenried, G. (2006), "What determines the speed of adjustment to the target capital structure?”, Applied Financial Economics, Vol. 16, pp. 941-958.

Eccles, R., Ioannou, I. and Serafeim, G. (2013), "The impact of a corporate sustainability on organizational processes and performance", HBS Working Paper Series 11-016.

El Ghoul, S., Guedhami, O., Kwok, C.C.Y. and Mishra, D.R. (2011), "Does corporate social responsibility affect the cost of capital?", Journal of Banking and Finance, Vol. 35, pp. 2388-2406.

Fama, E.F. and French, K.R. (2002), "Testing trade-off and pecking order predictions about dividends and debt", The Review of Financial Studies, Vol. 15 No. 1, pp. 1-33.

Fama, E.F. and French, K. (2007), "Disagreement, tastes, and asset prices", Journal of Financial Economics, Vol. 83 No. 3, pp. 667-689.

Flannery, M.J. and Rangan, K.P. (2006), "Partial adjustment toward target capital structures", Journal of Financial Economics, Vol. 79 No. 3, pp. 469-506.

Frank, M.Z. and Goyal, V.K. (2003), “Testing the pecking order theory of capital structure”, Journal of Financial Economics, Vol. 67, pp. 217-248.

Freeman, R.E. (1984), Strategic Management: A Stakeholder Approach, Pitman, Boston.

Freeman, R.E., Wicks, A.C. and Parmar, B.P. (2004), "Stakeholder theory and the corporate objective revisited", Organization Science, Vol. 15 No. 3, pp. 364-369.

Gaud, P, Jani, E., Hoesli, M. and Bender, A. (2005), "The capital structure of swiss companies: an empirical analysis using dynamic panel data", European Financial Management, Vol. 11, pp. 51-69.

Godlewski, C., Weill, L. and Turk Ariss, R. (2013), "Sukūk vs. conventional bonds: a stock market perspective”, Journal of Comparative Economics, Vol. 41 No. 3, pp. 745-761.

Graff Zivin, J. and Small, A. (2005), "A modigliani-miller theory of altruistic corporate social responsibility", B. E. Journals in economic analysis and policy, Topics in Economic Analysis and Policy, Vol. 5 No. 1, pp. 1-19.

Graham, J. and Harvey, C. (2001), "The theory and practice of corporate finance: evidence from the field", Journal of Financial Economics, Vol. 60 Nos 2-3, pp. 187-243.

Grassa, R. and Miniaoui, H. (2018), "Corporate choice between conventional bond and Sukūk issuance evidence from GCC countries", Research in International Business and Finance, Vol. 45, pp. 454-466. 
Hanifa, M., Masih, M. and Bacha, O. (2014), Testing Sukūk and Conventional Bond Offers Based on Corporate Financing Theories Using Partial Adjustment Models: Evidence from Malaysian Listed Firms, MPRA paper nb 56953, University Library of Munich, Munich.

Harris, M. and Raviv, A. (1991), "The theory of capital structure”, The Journal of Finance, Vol. 46, pp. determinants in GCC countries 297-355.

Hasib, A., Hassan, M.K. and Rayfield, B. (2017), "When and why firms issue sukuk?", Managerial Finance, Vol. 44 No. 2, pp. 774-786.

Heald, M. (1957), "Management's responsibility to society: the growth of an idea”, Business History Review, Vol. 31 No. 4, pp. 375-384.

Heinkel, R., Kraus, A. and Zechner, J. (2001), "The effect of green investment on corporate behavior", Journal of Financial and Quantitative Analysis, Vol. 36 No. 4, pp. 431-449.

Hovakimian, A. and Li, G. (2011), "In search of conclusive evidence: how to test for adjustment to target capital structure", Journal of Corporate Finance, Vol. 17, pp. 33-44.

Hovakimian, A., Opler, T. and Titman, S. (2001), "The debt-equity choice", Journal of Financial and Quantitative Analysis, Vol. 36, pp. 1-24.

$\mathrm{Hu}$, T.C. (2019), "The relationship between corporate social responsibility and sustainable financial performance: firm-level evidence from Taiwan", Corporate Social Responsibility and Environmental Management, Vol. 26, pp. 19-28.

Huang, R. and Ritter, J.R. (2009), "Testing theories of capital structure and estimating the speed of adjustment”, Journal of Financial and Quantitative Analysis, Vol. 44 No. 2, pp. 237-271.

Jalilvand, A. and Harris, R.S. (1984), "Corporate behavior in adjusting to capital structure and dividend targets: an econometric study", The Journal of Finance, Vol. 39, pp. 127-145.

Jensen, M.C. (1986), “Agency costs of free cash flow, corporate finance, and takeovers”, The American Economic Review, Vol. 76, pp. 323-329.

Jensen, K., Jakus, P., English, B. and Menard, J. (2002), Willingness to Pay for Environmentally Certified Hardwood Products by Tennessee Consumers, University of Tennessee, Department of Agricultural Economics, Knoxville, Study Series No. 01-02.

Kayo, E.K. and Kimura, H. (2011), "Hierarchical determinants of capital structure", Journal of Banking and Finance, Vol. 35, pp. 358-371.

Klein, P.O. and Weil, L. (2016), "Why do companies issue sukuk?", Review of Financial Economics, Vol. 31, pp. 26-33.

Klein, P.O., Turk Ariss, R. and Weil, L. (2017), "Religiosity vs. well-being effects on investor behavior", Journal of Economic Behavior and Organization, Vol. 138, pp. 50-62.

Kraus, A. and Litzenberger, R.H. (1973), “A state-preference model of optimal financial leverage”, The Journal of Finance, Vol. 33, pp. 911-922.

Lee, D.D. and Faff, R.W. (2009), "Corporate sustainability performance and idiosyncratic risk: a global perspective”, Financial Review, Vol. 44 No. 2, pp. 213-237.

Lemmon, M.L., Roberts, M.R. and Zender, J.F. (2008), "Back to the beginning: persistence and the crosssection of corporate capital structure", The Journal of Finance, Vol. 63 No. 4, pp. 1575-1608.

Long, M.S. and Malitz, E.B. (1985), "Investment patterns and financial leverage”, in Freidman, B. (Ed.), Corporate Capital Structures in the United States, University of Chicago Press, Chicago.

Maas, C.J. and Hox, J.J. (2005), "Sufficient sample sizes for multilevel modeling", Methodology: European Journal of Research Methods for the Behavioral and Social Sciences, Vol. 1, pp. 86-92.

Marsh, P. (1982), "The choice between equity and debt: an empirical study", The Journal of Finance, Vol. 37, pp. 121-144.

Marti, C.P., Rovira-Val, M.R. and Drescher, L.G.J. (2013), "Are firms that contribute to sustainable development better financially?”, Corporate Social Responsibility and Environmental Management, Vol. 22, pp. 305-319. 
IES

28,1

Miller, N., Challoner, J. and Atta, A. (2007), "UK welcomes the șukūk”, International Financial Law Review, Vol. 5 No. 26, pp. 24-25.

Modigliani, F. and Miller, M.H. (1958), "The cost of capital, corporation finance and the theory of investment", The American Economic Review, Vol. 48 No. 3, pp. 261-297.

Modirzadehbami, S. and Mansourfar, G. (2011), "Information content of islamic private debt announcement: evidence from Malaysia”, International Journal of Social, Human Science and Engineering, Vol. 5, pp. 69-75.

Mohamed, H.H., Masih, M. and Bacha, O.I. (2015),"Why do issuers issue Sukuk or conventional bond? Evidence from Malaysian listed firms using partial adjustment models", Pacific-Basin Finance Journal, Vol. 34, pp. 233-252.

Mohamed, M., Yahya, N.C., Che, N. and Ishak, N.A. (2017), "Market reactions towards the announcement of sukūk issuance: evidence from Malaysian market", Jurnal Pengurusan, Vol. 49, pp. 89-102.

Myers, S.C. (1977), "Determinants of corporate borrowing", Journal of Financial Economics, Vol. 9, pp. 147-175.

Myers, S.C. (1984), "The capital structure puzzle”, The Journal of Finance, Vol. 39 No. 3, pp. 574-592.

Myers, S.C. (2001), "Capital structure”, Journal of Economic Perspectives, Vol. 15, pp. 81-102.

Myers, S.C. and Majluf, N. (1984), "Corporate financing and investment decisions when firms have information that investors do not have”, Journal of Financial Economics, Vol. 13, pp. 187-221.

Nagano, N. (2010), Islamic Finance and Theory of Capital Structure, MPRA paper, University Library of Munich, Munich.

Nagano, N. (2016), "Who issues Sukūk and when?: an analysis of the determinants of Islamic bond issuance", Review of Financial Economics, Vol. 31, November pp. 45-55.

Nagano, N. (2017), "Sukuk issuance and information asymmetry: why do firms issue sukuk?", PacificBasin Finance Journal, Vol. 42, pp. 142-157.

Nathif, A.J. and Thomas, A. (2004), Islamic Bonds-Your Guide to Issuing, Structuring and Investing in Sukuk, Euromoney Books Ed, London.

Opler, T. and Titman, S. (1994), The Debt-Equity Choice: An Empirical Analysis, Corporate Finance \& Organizations from Ohio State University.

Ozkan, A. (2001), "Determinants of capital structure and adjustment to long run target: evidence from UK company panel data", Journal of Business Finance and Accounting, Vol. 28 Nos 1-2, pp. 175-198.

Paltrinieri, A., Hassan, M.K., Bahoo, S. and Khan, A. (2019), "A bibliometric review of sukuk literature", International Review of Economics and Finance, in Press.

Psillaki, M. and Daskalakis, N. (2009), "Are the determinants of capital structure country or firm specific?”, Small Business Economics, Vol. 33, pp. 319-333.

Rajan, R. and Zingales, L. (1995), "What do we know about capital structure? Some evidence from international data", Journal of Finance, Vol. 50 No. 5, pp. 1421-1460.

Shafron, E. (2019), "Investor tastes: implications for asset pricing in the public debt market", Journal of Corporate Finance, Vol. 55, pp. 6-27.

Shahida, S. and Sahara, S. (2013), "Why do firms issue șukūk over bonds? Malaysian evidence", Proceedings of the Eighth National Malaysian Conference on Economics.

Shyam-Sunder, L. and Myers, S.C. (1999), "Testing static trade-off against pecking order models of capital structure”, Journal of Financial Economics, Vol. 51, pp. 219-244.

Siddiqi, M.N. (1987), Partnership and Profit Sharing in Islamic Law, Islamic Economics Series 9, The Islamic Foundation, Leicester.

Smith, C. and Watts, R. (1992), "The investment opportunity set and corporate financing, dividend and compensation policies", Journal of Financial Economics, Vol. 32, pp. 263-292. 
Stulz, R. (1990), "Managerial discretion and optimal financing policies", Journal of Financial Economics, Vol. 26, pp. 3-27.

Taggart, R.A. (1977), “A model of corporate financing decisions”, The Journal of Finance, Vol. 32, pp. 1467-1484.

Titman, S. and Wessels, R. (1988), "The determinants of capital structure choice", The Journal of Finance, Vol. 43, pp. 1-19.

Ullah, S. and Jamali, D. (2010), "Institutional investors and corporate social responsibility: the role of Islamic financial institutions", International Review of Business Research Papers, Vol. 6 No. 1, pp. $619-630$.

Van Binsbergen, J.H., Graham, J.R. and Yang, J. (2011), "Optimal capital structure”, SSRN Electronic Journal, doi: 10.2139/ssrn.1743203.

Vasiliou, D., Eriotis, N. and Daskalakis, N. ( 2009), "Testing the pecking order theory: the importance of methodology", Qualitative Research in Financial Markets, Vol. 1 No. 2, pp. 85-96.

Wilson, R. (2008), "Innovation in the structuring of Islamic sukūk securities", Humanomics, Vol. 24 No. 3, pp. 170-181.

\section{Corresponding author}

Imene Guermazi can be contacted at: imeneguermazi@yahoo.fr

For instructions on how to order reprints of this article, please visit our website:

www.emeraldgrouppublishing.com/licensing/reprints.htm

Or contact us for further details: permissions@emeraldinsight.com 